\title{
Hubungan Antara Kecerdasan Emosional dan Motivasi Kerja dengan Komitmen Guru Terhadap Organisasi Sekolah Raudhatul Athfal Di Kota Bogor
}

\author{
Siti Wilda Malik*, Sumardi**, Djoehana S** \\ *Mahasiswa Program Studi Administrasi Pendidikan, Program Pascasarjana \\ ** Staf Dosen Program Studi Administrasi Pendidikan, Program Pascasarjana \\ Universitas Pakuan \\ Bogor, Indonesia
}

Diterima: 07 November 2015. Disetujui: 17 Desember 2015. Dipublikasikan: Januari 2016

\begin{abstract}
Abstrak
Penelitian ini bertujuan untuk mengetahui hubungan antara kecerdasan emosional dan motivasi kerja dengan komitmen guru terhadap organisasi. Penelitian ini dilaksanakan di Raudhatul Athfal se-Kota Bogor pada tahun 2015 dengan jumlah sampel sebanyak 131 orang yang diambil secara proporsional random sampling. Metode yang digunakan yaitu survei dan teknik analisis data menggunakan uji statistik korelasi dan regresi linier sederhana serta korelasi dan regresi linier ganda. Adapun pengujian hipotesis dilakukan pada taraf signifikan 0,05. Hasil penelitian menghasilkan tiga kesimpulan yaitu: Pertama: Terdapat hubungan positif yang sangat signifikan antara kecerdasan emosional dengan komitmen guru terhadap organisasi, yang ditunjukkan oleh koefisien korelasi $r_{\mathrm{y} 1}=0,307$ dan persamaan regresi $\hat{Y}=84,42+0,34 X_{1}$ Koefisien determinasi $r_{y 12}=0,094$, artinya kecerdasan emosional guru memberikan kontribusi sebesar $9,4 \%$ terhadap komitmen guru terhadap organisasi. Kedua: Terdapat hubungan positif yang sangat signifikan antara motivasi kerja dengan komitmen guru terhadap organisasi, yang ditunjukkan oleh koefisien korelasi $r_{y 2}=0,514$ dan persamaan regresi $\hat{Y}=59,94+0,54 X_{2}$. Koefisien determinasi $r_{y 2 y 2}=0,264$, artinya motivasi kerja memberikan kontribusi sebesar $26,4 \%$ terhadap komitmen guru terhadap organisasi. Ketiga: Terdapat hubu- ngan positif yang signifikan antara kecerdasan emosional dan motivasi kerja secara bersama-sama dengan komitmen guru terhadap organisasi koefisien korelasi ganda $r_{\mathrm{y} .12}=0,518$ dan persamaan $\hat{\mathrm{Y}}=20,141+$ $0,616 X_{1}+0,219 X_{2}$. Koefisien determinasi $r_{y .122}=0,268$, artinya kecerdasan emosional dan motivasi kerja secara bersama-sama memberikan kontribusi sebesar $26,8 \%$ terhadap komitmen guru terhadap orga- nisasi. Semakin baik kecerdasan emosional guru dan semakin tinggi motivasi kerja secara bersama-sama maka komitmen guru terhadap organisasi akan lebih meningkat.
\end{abstract}

(C) 2016 Program Pascasarjana Universitas Pakuan

KATA KUNCI: Keinovatifan Guru, Kompetensi Pedagogik, Kepemimpinan

\section{PENDAHULUAN}

Dalam era persaingan global setiap manusia dituntut untuk menguasai ilmu pengetahuan agar mampu bersaing dalam meningkatkan kualitas sumber daya manusia. Maka kualitas pendidikan harus ditingkatkan, karena sekolah dapat dijadikan sebagai tempat dalam menempa sumber daya manusia yang berkualitas. Hal ini tercantum dalam Undang-Undang Sisdiknas 
No.20 Pasal 3 Tahun 2003, bahwasannya diharapkan pendidikan mampu menghasilkan lulusan yang dapat mengembangkan kemampuan dan membentuk watak serta peradaban bangsa yang bermartabat dalam rangka mencerdaskan kehidupan bangsa yang bertujuan untuk mengembangkan potensi peserta didik agar menjadi manusia yang beriman dan bertakwa kepada Tuhan Yang Maha Esa, berakhlak mulia, sehat, berilmu, cakap, kreatif, mandiri dan bertanggung jawab.

Namun ironinya, potret kualitas dunia pendidikan di Indonesia saat ini masih rendah, yang menjadikan salah satu faktor penyebabnya adalah kurangnya loyalitas atau komitmen guru terhadap organisasi pendidikan (sekolah). Padahal guru merupakan faktor yang utama dalam mempengaruhi pelaksanaan kurikulum di sekolahnya. Oleh karena itu, dalam pelaksanaan kurikulum di sekolah harus diawali dengan adanya komitmen guru untuk lebih produktif, kreatif dan agresif dalam mencapai visi dan misi sekolah.

Komitmen guru terhadap organisasi merupakan hal amat penting dalam upaya meningkatkan mutu sekolah. Komitmen pasti akan mendorong rasa percaya diri dan semangat kerja guru. Komitmen akan memperlancar ketercapaian ultimate goal sekolah. Guru yang berkomitmen terhadap organisasi dapat ditandai dengan terciptanya peningkatan yang bersifat psikologis, sehingga segala sesuatunya menjadi menyenangkan bagi seluruh warga sekolah.

Komitmen guru terhadap organisasi tempatnya bekerja berperan dalam dunia pendidikan. Secara tidak langsung komitmen guru terhadap organisasi akan berdampak terhadap kualitas akademis maupun moral peserta didik. Bila komitmen guru terhadap organisasi tinggi maka prestasi belajar anak didik akan meningkat. Maka dapat diartikan bahwa komitmen ini memiliki peranan dalam mengembangkan kualitas peserta didik baik dari segi akademis maupun moral sehingga mereka akan mampu bersaing dalam era globalisasi saat ini.

Komitmen guru terhadap organisasi merupakan aspek prioritas yang harus diperhatikan. Guru sebagai kekuatan yang efektif dalam pelaksanaan pendidikan di sekolah sangat berperan dan bertanggung jawab terhadap perubahan, diantaranya perilaku guru yang mampu untuk memprakarsai pemikiran baru didalam proses interaksi di lingkungan sekolah dengan melakukan perubahan atau penyesuaian tujuan, sasaran, input, proses, ataupun output dari suatu sekolah sesuai dengan tuntutan perkembangan zaman.

Komitmen guru terhadap organisasi tempatnya bekerja yang tinggi dapat dilihat dari beberapa aspek diantaranya adalah: 1) perhatian terhadap peserta didik cukup tinggi ditandai dengan persentase kehadiran yang tinggi; 2) meluangkan banyak waktu dan tenaga melaksanakan tugas sehingga dapat bekerja secara profesional; dan 3) mengutamakan

kepentingan pekerjaan/organisasi.

Komitmen guru terhadap organisasi sangat penting dalam meningkatkan kualitas pembelajaran. Guru yang memiliki komitmen terhadap organisasi yang tinggi akan menyiapkan banyak waktu untuk melaksanakan tugas yang berkaitan dengan pembelajaran seperti, perancangan pengajaran, pengelolaan pengajaran dan senantiasa berpikir tentang cara untuk meningkatkan keefektifan prestasi belajar peserta didik. Bagi guru, pekerjaannya bukan sebagai beban atau kewajiban melainkan sarana berkarya dan mengembangkan diri, 
karena seorang guru mampu menjiwai pekerjaannya serta bekerja dengan pikiran dan hati.

Komitmen guru terhadap organisasi akan memberikan kontribusi dalam peningkatan kualitas layanan dan mutu pendidikan, responsif terhadap perubahan yang terjadi di masyarakat serta kemandirian lembaga pendidikan dalam menghadapi persaingan, tantangan dan tuntutan masyarakat. Upaya meningkatkan komitmen terhadap organisasi pada diri guru merupakan langkah strategis dalam meningkatkan kualitas pembelajaran. Peran guru sebagai pendidik tidak dapat digantikan oleh perangkat apapun, karena dalam pendidikan terkandung makna pengembangan nilai-nilai hidup yang menuntut interaksi yang humanis antara guru dan peserta didik.

Upaya meningkatkan komitmen guru terhadap organisasi pada diri guru merupakan langkah strategis dalam meningkatkan kualitas pembelajaran. Peran guru sebagai pendidik tidak dapat digantikan oleh perangkat apapun, karena dalam pendidikan terkandung makna pengembangan nilai-nilai hidup yang menuntut interaksi yang humanis antara guru dan peserta didik.

Dalam artikel ini akan dibahas tentang: 1. Hubungan antara Kecerdasan Emosional dengan Komitmen Guru terhadap Organisasi; 2. Hubungan antara Motivasi Kerja dengan Komitmen Guru terhadap Organisasi; 3. Apakah terdapat hubungan antara Kecerdasan Emosional dan Motivasi Kerja secara bersama-sama dengan Komitmen Guru terhadap Organisasi

\section{METODE}

Penelitian dilakukan di 27 sekolah Raudhatul Athfal Kota Bogor. Penelitian dilakukan pada bulan April sampai bulan September 2015.

Penelitian ini menggunakan metode survai dengan pendekatan korelasional. Penelitian bersifat non eksperimen dan tanpa intervensi peneliti terhadap variabelvariabel penelitian. Data didapat dengan menggunakan pernyataan berbentuk skala yang dikembangkan sendiri oleh peneliti.

Populasi dalam penelitian ini adalah guru-guru yang mengajar di sekolah Raudhatul Athfal Kota Bogor yang berjumlah 195 orang guru.

Teknik pengambilan sampel ini menggunakan rumus alokasi proportional random sampling dengan menggunakan rumus Slovin sebagai berikut:

\section{Statistik Deskriptif}

Untuk menguji hipotesis penelitian dilakukan analisis data. Pada analisis pendahuluan, dilakukan analisis dengan menggunakan statistik deskriptik, yaitu mendeskripsikan data masing-masing variabel yang telah terkumpul dari sampel penelitia yang meliputi penyajian data melalui tabel, grafik, diagram dan perhitungan modus, median mean, varians sampel, dan standar deviasi.

2. Uji Persyaratan Analisis Statistik Penelitian

Teknik statistik yang digunakan untuk menganalisis data sampel dan hasilnya diberlakukan untuk populasi. Statistik perametris merupakan jenis statistik inferensial digunakan untuk menguji parameter populasi melalui data sampel. Hasil dari penelitian ini dianalisis dengan menggunakan statistik parametrik setelah memenuhi syarat, yaitu: data berdistribusi normal, hubungan yang linier dan data bersifat homogen. 
a. Uji Normalitas Galat Baku (Y- $\hat{Y})$ dengan menggunakan Uji Lilifors

Pengujian ini dilakukan untuk mengetahui normal atau tidaknya distribusi data, hal ini penting karena berkaitan ketepatan pemilihan uji statistik yang akan dipergunakan. Uji galat baku taksiran dilakukan untuk mengetahui apakah variabel komitmen guru terhadap organisasi $(Y)$ atau variabel kecerdasan emosional $\left(X_{1}\right)$ dan motivasi kerja $\left(X_{2}\right)$ berasal dari populasi yang berdistribusi normal. Syarat normal adalah jika nilai uji $L_{\text {hitung }}<L_{\text {tabel, }}$ maka data tersebut berada pada distribusi normal.

b. Homogenitas Varians $\mathrm{Y}$ atau $\mathrm{X}$ dengan Menggunakan Uji Barlett

Uji ini dimaksud untuk menguji kesamaan varians populasi yang berdistribusi normal. Uji homogenitas yang digunakan ialah $\mathrm{Uji}$ Barlett Varians dinyatakan homogeny bila $\mathrm{X}_{2} \mathrm{~h}<\mathrm{X}_{2}$ t diuji dengan taraf signifikansi 0,05 . Pengujian ini dilakukan untuk mengetahui homogenitas data dalam populasi atau apakah sampel penelitian diambil dari populasi yang sama. Uji varians dilakukan untuk mengetahui apakah variabel kepuasan kerja (Y) atau kepemimpinan transformasional kepala sekolah $\left(\mathrm{X}_{1}\right)$ dan motivasi berprestasi $\left(\mathrm{X}_{2}\right)$, berasal dari populasi yang homogeni.

Uji linieritas dengan menggunakan uji $F$, apabila nilai $F_{\text {hitung }}<F_{\text {tabel, }}$ maka analisis regresi dapat dilanjutkan.Uji Hipotsisan ini teknik analisis data yang digunakan adalah teknik analisis korelasional dengan menggunakan Correlational Pearson Product Moment $(r)$, bertujuan untuk mengetahui hubungan antara variabel bebas $(X)$ dengan variabel terikat $(\mathrm{Y})$. Teknik korelasi yang digunakan pada penelitian ini adalah:

1) Teknik Korelasi Sederhana Correlational Pearson Product Moment dilambangkan dengan ( $r)$, dengan ketentuan nilai $r$ tidak lebih dari harga $1<r<+1$. Apabila $r=-1$ artinya korelasinya negatif sempurna; $r=0$ artinya tidak ada hubungan; $r=+1$ berarti korelasinya negatif sempurna; $r=0$ artinya tidak ada hubungan; $r=+1$ berarti koresinya sangat kuat.

2) Teknik Korelasi Ganda

dengan menghitung Fhitung dengan rumus: Kaidah pengujian signifikansi yaitu dengan membandingkan Fhitung dengan Ftabel, jika Fhitung > Ftabel, maka signifikan.

a) Regresi Sederhana, dengan rumus persamaan regresi: dengan menguji signifikansi yaitu jika Fhitung > Ftabel maka signifikan.

b) Regresi Ganda. Tujuan analisis ganda adalah untuk meramalkan nilai variabel terikat $(Y)$ apabila variabel bebas minimal 2 atau lebih, tujuannya untuk membuktikan ada tidaknya hubungan fungsi antara dua variabel bebas atau lebih. Uji regresi ganda pada penelitian ini.

\section{HASIL DAN PEMBAHASAN}

A. Uji Prasyarat Analisis

1. Uji Normalitas Galat Baku Data Komitmen Guru terhadap Organisasi $(Y)$ atas Kecerdasan Emosional $\left(\mathrm{X}_{1}\right)$

Hasil perhitungan uji normalitas galat baku taksiran $\left(Y-\hat{Y}_{1}\right)$ variabel komitmen guru terhadap organisasi $(Y)$ atas variabel kecerdasan emosional $\left(\mathrm{X}_{1}\right)$ diperoleh dari nilai $L_{\text {hitung }}=0.0522$ sedangkan nilai $L_{\text {tabel }}=$ 0,07741. Persyaratan normal adalah Lhitung< Ltabel, dengan demikian galat baku taksiran $\left(Y-\hat{Y}_{1}\right)$ variabel komitmen guru terhadap organisasi $(Y)$ atas variabel kecerdasan emosional $\left(X_{1}\right)$ berasal dari populasi yang berdistribusi normal. 
2. Uji Normalitas Galat Baku Data Komitmen Guru terhadap Organisasi ( $Y$ ) atas Motivasi Kerja Guru $\left(\mathrm{X}_{2}\right)$

Hasil perhitungan uji normalitas galat baku taksiran ( $\mathrm{Y}-\hat{\mathrm{Y}} 1$ ) variabel Komitmen Guru terhadap Organisasi $(\mathrm{Y})$ atas variabel Motivasi Kerja $\left(\mathrm{X}_{2}\right)$ diperoleh nilai Lhitung = 0,066164 sedangkan nilai $L_{\text {tabel }}=0,07741$. Persyaratan normal adalah $\mathrm{L}_{\text {Hitung }}<\mathrm{L}_{\text {Tabel, }}$ dengan demikian galat baku taksiran $\left(\mathrm{Y}-\hat{\mathrm{Y}}_{1}\right)$ variabel Komitmen Guru terhadap Organisasi $(\mathrm{Y})$ atas variabel Motivasi Kerja $\left(\mathrm{X}_{2}\right)$ berasal dari populasi yang berdistribusi normal.

3. Uji Homogenitas Kecerdasan Emosional $\left(X_{1}\right)$

Pengujian homogenitas dilakukan dengan menggunakan uji Bartlett. Berdasarkan hasil pengujian diperoleh nilai $\chi_{\text {hitung }}^{2}=19,272$ sedangkan $\chi_{\text {tabel }}^{2}=42,557$. Persyaratan data tersebut homogen bila $\chi_{\text {hitung }}^{2}<\chi_{\text {tabel. }}^{2}$ Hal tersebut bermakna bahwa kelompok data Komitmen Guru terhadap Organisasi $(\mathrm{Y})$ atas Kecerdasan Emosional $\left(X_{1}\right)$ berasal dari populasi yang homogen.

4. Uji Homogenitas Komitmen Guru terhadap Organisasi ( $\mathrm{Y}$ ) atas Motivasi $\operatorname{Kerja}\left(\mathrm{X}_{2}\right)$

Pengujian homogenitas varians data Komitmen Guru terhadap Organisai atas Motivasi Kerja dilakukan dengan menggunakan uji Bartlett. Berdasarkan hasil pengujian diperoleh nilai $\chi_{\text {hitung }}^{2}=21,673$ sedangkan $\chi_{\text {tabel }}^{2}=42,557$. Persyaratan data tersebut homogen bila $\chi^{2}$ hitung $<\chi_{\text {tabel. }}^{2}$ Hal tersebut bermakna bahwa kelompok data Komitmen Guru terhadap Organisasi $(\mathrm{Y})$ atas Motivasi Kerja $\left(\mathrm{X}_{2}\right)$ berasal dari populasi yang homogen.
B. Pengujian Hipotesis

1. Hubungan antara variabel Kecerdasan Emosional dengan Komitmen Guru terhadap Organisasi

Hipotesis pertama yang diajukan dalam penelitian ini adalah terdapat hubungan positif antara Kecerdasan Emosional $\left(X_{1}\right)$ dengan Komitmen Guru terhadap Organisasi (Y).

Hipotesis yang menyatakan bahwa terdapat hubungan positif antara variabel Kecerdasan Emosional $\left(\mathrm{X}_{1}\right)$ dengan Komitmen Guru terhadap Organisasi $(Y)$ diuji dengan analisis regresi sederhana. Perhitungan analisis regresi sederhana menghasilkan koefisien korelasi $r_{\mathrm{y} 1}$ sebesar $0,307>r_{\text {tabel }}=2,617$ pada $\alpha=0,05$ yang berarti Hipotesis yang menyatakan bahwa terdapat hubungan positif antara Kecerdasan Emosional $\left(X_{1}\right)$ dengan Komitmen Guru terhadap Organisasi (Y) dapat diterima, artinya makin tinggi Kecerdasan Emosional Guru maka akan diikuti makin tinggi pula Komitmen Guru terhadap Organisasi. Koefisien determinan $\left(r^{2}{ }_{y 1}\right)$ sebesar 0,094 yang berarti faktor Kecerdasan Emosional berperan atau memberikan kontribusi sebesar 9,4\% terhadap Komitmen Guru terhadap Organisasi sedangkan 90,6\% dipengaruhi oleh faktor lain.

2. Hubungan antara variabel Motivasi Kerja dengan Komitmen Guru terhadap Organisasi

Hipotesis kedua dalam penelitian ini adalah terdapat hubungan positif antara Motivasi Kerja $\left(\mathrm{X}_{2}\right)$ dengan Komitmen Guru terhadap Organisasi (Y). Analisis linier sederhana antara Motivasi Kerja dengan Komitmen Guru terhadap Organisasi memiliki persamaan regresi $\hat{Y}=59,94+$ 
$0,54 \mathrm{X}_{2}$ dengan arah koefisien regresi sebesar 0,54 dan konstanta sebesar 59,94.

Pengujian kebenaran hasil regresi dimaksudkan untuk menguji hipotesis tentang adanya hubungan positif antara Motivasi Kerja $\left(\mathrm{X}_{2}\right)$ dengan Komitmen Guru terhadap Organisasi $(Y)$, untuk itu diperlukan uji signifikasi dan linier terhadap persamaan regresi dengan menggunakan uji $F$.

Berdasarkan hasil uji keberartian persamaan regresi diperoleh $F_{\text {hitung }}$ sebesar 161,069 sedangkan $F_{\text {tabel }}$ sebesar 6,810 yang berarti $F_{\text {hitung }}>\quad F_{\text {tabel. }}$ Hal tersebut menunjukkan bahwa hubungan antara variabel Motivasi Kerja $\left(X_{2}\right)$ dengan Komitmen Guru terhadap Organisasi ( $Y$ ) adalah sangat signifikan.

Uji linieritas dengan uji $F$ dilakukan untuk menguji apakah persamaan regresi tersebut linier atau tidak. Persamaan regresi dikatakan linier apabila $F_{\text {hitung }}>F_{\text {tabel }}$. Berdasarkan hasil perhitungan yang terdapat pada tabel, diperoleh nilai $F_{\text {hitung }}$ sebesar 1,533 sedangkan nilai $F_{\text {tabel }}$ adalah 1,540, yang berarti nilai $F_{\text {hitung }}<F_{\text {tabel }}$. Pada uji $t$ diperoleh thitung sebesar 19,016 pada $t_{\text {tabel }}$ 2,576 . Dengan demikian persamaan regresi $\hat{Y}$ $=59,94+0,54 X_{2}$ dapat dinyatakan linier dan disimpulkan persamaan regresi tersebut adalah linier dan sangat signifikan.

Hipotesis yang menyatakan bahwa terdapat hubungan positif antara variabel Motivasi Kerja $\left(X_{2}\right)$ dengan Komitmen Guru terhadap Organisasi $(\mathrm{Y})$, diuji dengan analisis regresi sederhana. Perhitungan analisis sederhana menghasilkan koefisien koreasi $r_{\mathrm{yz}}$ sebesar $0,518>r_{\text {tabel }}=3,066$ pada $\alpha=0,05$ yang berarti yang: Hipotesis yang menyatakan bahwa terdapat hubungan positif antara Motivasi Kerja $\left(X_{2}\right)$ dengan Komitmen Guru terhadap Organisasi ( $Y$ ) dapat diterima, artinya makin baik Motivasi Kerja maka akan diikuti makin baik pula Komitmen Guru terhadap Organisasi. Koefisien determinan $r_{\text {y2 }}^{2}$ sebesar 0,264 yang berarti faktor Motivasi Kerja berperan/memberikan kontribusi sebesar 26,4\% terhadap Komitmen Guru terhadap Organisasi sedangkan $73,6 \%$ dipengaruhi oleh faktor lain.

3. Hubungan antara Variabel Kecerdasan Emosional $\left(\mathrm{X}_{1}\right)$ dan Motivasi Kerja $\left(\mathrm{X}_{2}\right)$ secara Bersama-sama dengan Komitmen Guru terhadap Organisasi ( $Y$ )

Hipotesis ketiga yang diajukan dalam penelitian ini adalah terdapat hubungan positif antara Kecerdasan Emosional $\left(X_{1}\right)$ dan Motivasi Kerja $\left(X_{2}\right)$ secara bersama-sama dengan Komitmen Guru terhadap Organisasi (Y). Analisis linier ganda antara Kecerdasan Emosional dan Motivasi Kerja secara bersama-sama dengan Komitmen Guru terhadap Organisasi memiliki persamaan regresi $\hat{Y}=20,141+0,616 X_{1}+0,219 X_{2}$ dengan arah koefisien regresi $a_{1}$ sebesar $0,616, a_{2}$ sebesar 0,219 dan konstanta sebesar 20,141. Pengujian mengenai kebenaran hasil regresi tersebut, juga dimaksudkan untuk menguji hipotesis tentang adanya hubungan positif antara Kecerdasan Emosional $\left(X_{1}\right)$ dan Motivasi Kerja $\left(X_{2}\right)$ secara bersama-sama dengan Komitmen Guru terhadap Organisasi (Y), maka diperlukan uji signifikasi dan linier terhadap persamaan regresi dengan menggunakan uji F.1.

Berdasarkan hasl uji keberartian persamaan regresi linier ganda diperoleh

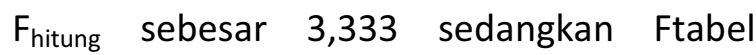
sebesar 4,78 yang berarti nilai $F_{\text {hitung }}>F_{\text {tabel }}$. $\mathrm{Hal}$ tersebut menunjukkan bahwa $\mathrm{HO}$ ditolak, artinya $\mathrm{H}_{1}$ yang menyatakan terdapat hubungan positif antara Kecerdasan Emosional $\left(X_{1}\right)$ dan Motivasi Kerja $\left(X_{2}\right)$ secara bersama-sama dengan 
Komitmen Guru terhadap Organisasi (Y) diterima.

Hubungan antara variabel Kecerdasan Emosional $\left(X_{1}\right)$ dan Motivasi Kerja $\left(X_{2}\right)$ secara bersama-sama dengan Komitmen Guru terhadap Organisasi (Y), ditunjukkan oleh koefisien korelasi $r_{y .12}$.

Berdasarkan hasil perhitungan diperoleh $r_{y .12}$ sebesar 0,518 yang berarti hubungan antara variabel Kecerdasan Emosional $\left(\mathrm{X}_{1}\right)$ dan Motivasi Kerja $\left(\mathrm{X}_{2}\right)$ secara bersama-sama dengan Komitmen Guru terhadap Organisasi $(\mathrm{Y})$ sangat kuat/tinggi. Nilai koefisien determinan $\left(r_{y .12}^{2}\right)$ sebesar 0,268 yang berarti faktor Kecerdasan Emosional dan Motivasi Kerja secara bersama-sama berperan atau memberikan kontribusi sebesar 26,4\% terhadap Komitmen Guru terhadap Organisasi.

\section{Uji Korelasi Parsial}

Hasil perhitungan korelasi antara $X_{1}$ dengan $Y$ diperoleh koefisien korelasi sebesar $r_{y .1}=0,307$ sedangkan hasil perhitungan uji korelasi parsial dengan pengendali $X_{2}$ diperoleh $r_{y .1}=0,307>r_{\text {tabel }}=$ 1,960 pada $\alpha=0,05$. Hal ini berarti bahwa hubungan antara Kecerdasan Emosional dan Komitmen Guru terhadap Organisasi tetap signifikan apabila dikontrol oleh variabel Motivasi Kerja, dengan kata lain hubungan antara Kecerdasan Emosional dengan Komitmen Guru terhadap Organisasi tidak dipengaruhi secara signifikan oleh Motivasi Kerja.

Berdasarkan hasil perhitungan korelasi antara $X_{2}$ dengan $Y$ diperoleh koefisien korelasi sebesar $r_{y .2}=0,744$ sedangkan hasil perhitungan uji korelasi parsial dengan pengendali $X_{1}$ diperoleh $r_{y .2}=0,744>r_{\text {tabel }}=$ 0,176 pada $\alpha=0,05$. Hal ini berarti bahwa hubungan antara Motivasi Kerja dan Komitmen Guru terhadap Organisasi juga tetap signifikan apabila dikontrol oleh variabel Kecerdasan Emosional, dengan kata lain hubungan antara Motivasi Kerja dengan Komitmen Guru terhadap Organisasi tidak dipengaruhi secara signifikan oleh Kecerdasan Emosional.

5. Hubungan Positif antara Kecerdasan
Emosional dengan Komitmen Guru
terhadap Organisasi
Kekuatan hubungan antara Kecerdasan Emosional dengan Komitmen Guru terhadap Organisasi ditunjukkan dengan koefisien korelasi $r_{\mathrm{y} 1}=0,307$ dengan koefisien determinasi $r_{y 1}^{2}=0,094$ menunjukkan bahwa 9,4\% Komitmen Guru terhadap Organisasi dapat dihasilkan dari adanya variabel Kecerdasan Emosional. Hubungan fungsional antara Kecerdasam Emosional dengan Komitmen Guru terhadap Organisasi memberikan arti bahwa semakin tinggi Kecerdasan Emosional diikuti dengan peningkatan komitmen guru terhadap organisasinya semakin baik.

Maka jelas bahwa komitmen guru terhadap organisasi sangat dipengaruhi oleh kecerdasan emosional yang tepat. Hendaknya lebih melibatkan guru pada pencapaian visi misi sekolah. Kepala Sekolah hendaknya juga memberi pengaruh dan keteladanan kepada guru agar dapat meningkatkan komitmen guru terhadap organisasi.

6. Hubungan Positif antara Motivasi Berprestasi Guru dengan Kepuasan Kerja Guru

Kekuatan hubungan antara Motivasi Kerja dengan Komitmen Guru terhadap Organisasi ditunjukkan dengan koefisien korelasi $r_{y 2}=0,514$ dengan koefisien determinasi $r_{y 2}^{2}=0,264$, hal ini berarti bahwa variabel Motivasi Kerja memberikan 
kontribusi sebesar 26,4\% terhadap Komitmen Guru terhadap Organisasi.

Hubungan fungsional antara Motivasi Kerja dengan Komitmen Guru terhadap Organisasi ditunjukkan dengan persamaan regresi $\hat{Y}=59,94+0,54 X_{2}$. Hubungan antara kedua variabel ini adalah sangat signifikan dan linier, artinya apabila Motivasi Kerja ditingkatkan sebesar satu satuan maka produktivitas kerja guru diprediksi akan meningkat sebesar 0,54 satuan dengan konstanta sebesar 59,94. Hal ini memberikan arti bahwa semakin tinggi Motivasi Kerja maka Komitmen Guru terhadap Organisasi akan menjadi semakin baik. Motivasi Kerja memberikan sumbangan positif bagi peningkatan Komitmen Guru terhadap Organisasi.

7. Hubungan positif antara Kecerdasan Emosional dan Motivasi Kerja secara Bersama-sama dengan Komitmen Guru terhadap Organisasi

Hubungan secara bersama-sama antara variabel Kecerdasan Emosional dan Motivasi Kerja dengan Komitmen Guru terhadap Organisasi memiliki koefisien korelasi sebesar $r_{y .12}=0,518$ dan koefisien determinasi $r^{2}{ }_{y 1.2}=0,268$ sehingga dapat diartikan bahwa 26,8\% Komitmen Guru terhadap Organisasi dapat dihasilkan melalui variabel Kecerdasan Emosional dan Motivasi Kerja secara bersama-sama.

Koefisien determinasi variabel Motivasi Kerja sebesar $26,4 \%$ relatif lebih tinggi jika dibandingkan dengan koefisien determinasi variabel Kecerdasan Emosional yaitu sebesar 9,4\%. Perbedaan perolehan nilai koefisien determinasi antara kedua variabel secara sendiri-sendiri tersebut memberikan makna bahwa berdasarkan penilaian responden, faktor Motivasi Kerja ternyata memberikan sumbangan yang lebih positif dan signifikan bagi Komitmen Guru terhadap Organisasi. Namun koefisien determinasi Kecerdasan Emosional dan Motivasi Kerja secara bersama-sama sebesar $26,8 \%$, nilai ini lebih besar jika dibandingkan dengan koefisien determinasi Kecerdasan Emosional dan Motivasi Kerja secara sendiri-sendiri. Hal ini menunjukkan makna bahwa menurut penilaian responden, kedua faktor Kecerdasan Emosional dan Motivasi Kerja secara bersama-sama ternyata memberikan sumbangan yang sangat signifikan bagi peningkatan Komitmen Guru terhadap Organisasi.

Kecerdasan Emosional dan Motivasi Kerja yang berkorelasi secara bersama-sama merupakan faktor yang paling menunjang untuk mencapai Komitmen Guru terhadap organisasi yang maksimal. Dengan Kecerdasan Emosional yang baik, maka seorang guru dapat termotivasi dirinya dengan baik sehingga dapat mencapai Komitmen Guru terhadap Organisasi yang baik dan mewujudkan tujuan yang ingin dicapai.

Berdasarkan hasil penelitian dan pembahasan di atas, maka dapat disimpulkan bahwa terdapat hubungan yang positif antara Kecerdasan Emosional dengan Komitmen Guru terhadap Organisasi, Motivasi Kerja dengan Komitmen Guru terhadap Organisasi, dan Kecerdasan Emosional dan Motivasi Kerja secara bersama-sama dengan Komitmen Guru terhadap Organisasi.

\section{PENUTUP}

Penelitian dilakukan bertujuan untuk mengetahui hubungan antara Kecerdasan Emosional dan Motivasi Kerja dengan Komitmen Guru terhadap Organisasi, menghasilkan kesimpulan sebagai berikut: 
Terdapat hubungan positif yang sangat signifikan antara kecerdasan emosional dengan komitmen terhadap organisasi guru dan kontribusi kecerdasan emosional sebesar 9,4\% dalam meningkatkan komitmen guru terhadap organisasi.

Terdapat hubungan positif yang sangat signifikan antara motivasi kerja dengan komitmen guru terhadap organisasi. Kontribusi motivasi kerja sebesar 26,4\% dalam meningkatkan komitmen guru terhadap organisasi.

Terdapat hubungan positif yang signifikan antara kecerdasan emosional dan motivasi kerja secara bersama-sama dengan komitmen guru terhadap organisasi. Kontribusi kecerdasan emosional dan motivasi kerja secara bersama-sama sebesar $26,8 \%$ dalam meningkatkan komitmen guru terhadap organisasi.

\section{DAFTAR PUSTAKA}

Bobby, De \& Hernacki, M. (2011). Quantum Learning: Membiasakan Belajar Nyaman dan Menyenang- kan, terj. Alwiyah Abdurrahman. Bandung: Kaifa

Colquitt, J.A., Lepine, J.A \& Wesson, M.J. (2009). Organizational Behavior Improving Performance and Commitment in the Workplace. New York : Mc Graw - Hill/Irwin.

Dahlia, L. (2014). Hubungan antara Kecerdasan Emosional dan Motivasi Kerja dengan Komitmen Terhadap Organisasi Guru SD Negeri Bojonggede. PPs UNPAK: Tesis tidak diterbitkan.

Djaali. (2011). Psikologi Pendidikan. Jakarta: Bumi Aksara.

Gibson, J.L., Jhon M. Ivancevich, James H. Donnelly Jr., \& Robert Konopaske .(2012). Organizations: Behavior, Structure Processes. Fourteenth Edition. New York: The Mc Graw-Hill Companies, Inc.

Ginanjar, A.A. (2009). ESQ : Emotional Spiritual Quotient. Jakarta: Arga Publishing.

Hujaemah, H. (2013). Hubungan antara Kepemimpinan Situasional dan Motivasi Kerja dengan Komitmen Organisasional Guru SMP
Swasta di Kecamatan Cikole Kota Sukabumi. PPs Unpak: Tesis tidak diterbitkan

Koswara, D \& Halimah. (2008). Seluk Beluk Profesi Guru. Bandung: Pribumi Mekar

Mulyasa, E. (2007). Menjadi Guru Profesional: Menciptakan Pembelajaran Kreatif dan Menyenangkan. Bandung: Remaja Rosdakarya

Reuven, B. (2001). Emotional Intelligence and SelfActualization, Emotional Intelligence in Everyday Life: A Scientific Inquiry. America: Psychology Press Taylor \& Francis

Rivai, V \& Mulyadi, D. (2012). Kepemimpinan dan Perilaku Organisasi. Jakarta: Rajawali Pers.

Suhardi, E. (2012). Modul Teknik Analisis Data; Kalibrasi Instrumen. Bogor: Program Pascasarjana Unpak.

Surbakti, E.B. (2012). Management Perusahaan: Solusi Cerdas Meningkatkan Profit. Jakarta: Praninta Aksara,

Sutrisno, E. (2011). Budaya Organisasi. Jakarta: Kencana

Sudjana. (2005). Metode Statistika. Bandung: Tarsito

Sugiyono. (2011). Metode Penelitian Pendidikan: Pendekatan Kuantitatif, Kualitatif, dan $R \& D$. Bandung: Alfabeta

Syamsudin, A. M. (2009). Psikologi Kependidikan. Bandung: Remaja Rosdakarya.

Taylor, R. (2008). The Complete Mind Make Over Ubahlah Hidup Anda untuk Mencapai Sukses, Terj. Lusiana Rimintang. Jakarta: Erlangga.

Triyono, A. (2012). Paradigma Baru Manajemen Sumber Daya Manusia: Kunci Sukses Meningkatkan Kinerja, Produktivitas, Motivasi, dan Kepuasan Kerja. Yogyakarta: Oryza.

Wibowo. (2012). Manajemen Kerja. Jakarta: Raja wali Pers.

Wipperman, J. (2006). Meningkatkan Kecerdasan Emosional, terj. Winianto. Jakarta: Prestasi Pustakaraya, 2006 